\title{
Analysis of College Education Art Curriculum and Its Impact on Teacher Productivity at Primary Schools. The Case of Northern Ghana
}

\author{
Hamza Alhassan $^{1 *} \quad$ Mohammed Issah Seini $^{2} \quad$ Fuseini Mahamadu $^{1}$ \\ 1.Department of Pre-vocational Skills, Tamale College Education, P. O. Box E/R 1, Tamale, Ghana \\ 2.Industrial Art Department, Tamale Technical University, P. O. Box E/R 3, Tamale, Ghana
}

\begin{abstract}
This article examines the art curriculum at the colleges of education that prepares teachers at pre-service to teach creative art at the primary schools in Ghana with a focus on the northern region of the country. The study also assesses pupils' knowledge and skills in the teaching and learning of creative art and reveals the teachers' professional competencies of teaching creative art at the primary level. The article argues that the current teaching and learning of art as a subject at the primary schools requires improvement in the use of teaching and learning tools for effective classroom activities. Also, the quality of training received by teachers at pre-service is among factors that influence the current conditions of teaching and learning of creative arts at the primary level. The study reveals a mismatch in the relationship between the colleges of education curriculum and the basic school creative arts subject. The article suggests that the teacher training curriculum in creative arts that prepares teachers for Basic schools in Ghana and the Creative Arts syllabus for schools in Ghana are properly aligned in content knowledge. Adopting the qualitative and quantitative inquiry with descriptive and survey research methods, the instruments used for the data collection were questionnaire and interview.
\end{abstract}

Keywords: Creative arts, art, curriculum, primary, college, education

DOI: $10.7176 / \mathrm{JEP} / 11-17-15$

Publication date:June 30th 2020

\section{Introduction}

Interactions with some teachers in the Northern Region of Ghana have revealed that graduates from institutions that offer Pre-Vocational Skills Visual Art Related Subjects and those that study Visual Art Related Subjects from Colleges of Education reveals inadequacy in basic practical skills set, content knowledge, and pedagogical needed to teach Creative Arts in basic schools. It is observed that students who have a natural talent in art are challenged in their effort to build on this talent after graduating from basic school. Students who would like to study arts further also get discouraged and give up on this quest since their interest have not been nurtured and sustained and rather develop the interest for other subjects. This suggests the need to assess the support systems that could enable effective teaching of Creative Arts at the Basic school level and generate interest in the arts to foster the development of creativity and promote technical /vocational education. This prompted the interest of this article which sought to examine the college education art curriculum and the teaching of creative arts at the primary schools in the Northern Region of Ghana.

\section{Research Objectives}

The main objective of the paper is to assess the type of pre-service training given to teacher trainees at the colleges of education to enable them effectively teach creative art subject at the primary schools with a specific focus on the following objectives:

1. Evaluate the curriculum studied by teacher trainees at the colleges of education?

2. Assess the level of pedagogical content knowledge taught by teachers at the primary schools?

3. Find out the relationship between the colleges of education curriculum and the primary school curriculum?

4. Assess the use of teacher and learner resources in teaching creative arts?

\section{Review of Related Literature}

\subsection{Teacher Education and Training}

Teachers are directly involved in the organization of students' learning experiences and therefore very essential agents in the educational process (Guadalupe, 2010). Because teachers are crucial in determining what happens in the classroom, teacher education, training, and qualification are also of prime importance in the educational system (Rouse, 2008). Hollins (2011) explains that teacher education is geared towards providing opportunities for prospective teachers to gain profound awareness and understanding in different areas, acquire specialized skills and practices, as well as requirements of teaching and presentation to facilitate learning. Teacher education is also identified with the improvement of teacher capability and competence that empowers and enables 
teachers to acquire the prerequisite of the educational system (Njui, 2017).

Hollins (2011) explains that going through training to become a teacher is a complex process that is determined by the ability to create and relate understanding from various areas to build knowledge that can facilitate learning in difficult and varied situations. Teacher training is an accepted institution worldwide but the nature of the institutions varies within and across countries, depending on the quality of the faculties who do the training and the programs that are run (Scott, 2005). Teacher training and certification are measures that are put in place to ensure teacher quality so they are well equipped for the huge role they play in the lives of their students and the society at large. Farrant (1982) therefore reasons that the goal of teacher education is to prepare teacher-trainees with academic and professional qualities that include a sound knowledge of the subject matter they are required to teach.

Teacher training is a curriculum designed to equip prospective teachers with the knowledge, attitudes, behavior, and skills they need to perform their tasks effectively in the classroom, school and the wider community (Wikipedia, 2014). In a general perspective, teacher training is characterized under an Initial teacher training education stage which has to do with a pre-service course before entering the classroom as a fully responsible teacher; an Induction stage which is the process of providing training and support during the first few years of teaching or the first year in a particular school; and a teacher development or continuing professional development which is an in-service process for practicing teachers (Anamuah-Mensah, 2011).

In Australia, teacher education programs are offered in colleges and universities as a three-year course leading to a diploma in teaching at the early childhood or primary education levels. The universities commonly offer a first degree in the science, social science, or humanities area, followed by a one-year education course which leads to a Diploma of Education and Secondary Teaching. Some universities also offer a four-year B.Ed. program. There is also the option of Bachelor of Art or Diploma in Education (DipEd) which can also be used for early childhood and primary school teaching (UNESCO, 1990) as cited Asuamah, 2015). In the case of teacher education for art teaching, mentions several universities in the USA, UK, and Canada who prepare teachers through arts-based curricula and studio-based education programs which lead to 3-year Bachelor of Arts, 4-year Bachelor of Art (Honours), 5-year Bachelor of Arts Integrated Studies (Honours), Bachelor of Education or Bachelor of Art (Honours), and 4-year Bachelor of Science degrees that combine Art, Education and Science courses for Art students. However, others like the University of Texas and Brock University offer Education programs alongside their Art program and so offer certificates in Education as evidence of professional development and licensing for teaching art.

\subsection{Teacher Professional Development}

Professional development refers to a structure of systematic activities that prepare professionals like teachers for their occupation; these include initial training, induction courses, in-service training, and continuous professional formation within institutional settings (Nicholls, 2014). The nature of the institutions that train teachers varies within and across countries in terms of the quality of faculties and the specific nature of the programs even in a single continent (International Reading Association, 2008). The universities' commonest pattern is a first degree in the sciences, social sciences, or humanities area, followed by a one-year education course which leads to a Diploma in Education and Secondary Teaching. Some universities also offer a four-year Bachelor of Education program. There is also the option of a Bachelor of Art or Diploma in Education which can also be used for early childhood and primary school teaching (UNESCO, 1990) as cited Asuamah, 2015).

Distance learning modes of teacher education are also being deployed as an in-service vehicle to upgrade the knowledge, skills, and qualifications of an existing teaching force. Nicholls (2014) further adds that, within developed countries, distance education, mainly in the form of Web-based education, serves as a vehicle for continuing education, offering enrichment, enhancement and additional certifications for teachers who have gotten at least a minimum level of certification for their content and grade level.

\subsection{Teacher Education in Ghana}

Teacher training in Ghana has a national focus (Anamuah-Mensah and Benneh, 2000, as cited in Asare \& Nti, 2014. The authors add that, typical to Ghana's teacher education drives, teacher training utilizes the generalist and subject-training approaches; generalist teachers are produced for Kindergarten (KG) and Primary classes 1 6; and specialist teachers for Junior High Schools (JHS) and Senior High Schools (SHS). According to Adegoke (2003) as cited in Asare and Nti (2014) and Benneh (2006), the mission of Ghana's teacher education is to provide a comprehensive teacher education program through pre- and in-service training that would produce skillful, dedicated and committed instructors to improve the quality of teaching and learning. Adu-Yeboah (2016) explains that the training of teachers is organized in colleges of education (formerly teacher training colleges), the UCC, and UEW. The colleges of education train teachers for the Basic School level (Preschool through to Basic 9), while the universities prepare teachers for all levels, though many of their products prefer to teach in post-basic institutions. 
Antwi (1992) as cited in Afum-Danso (2012) has observed that teacher training at all public CoE in Ghana is residential, basically public, and mostly attended by members of both sexes. Until the 1990s, two systems (post-middle and post-secondary) existed for pre-teacher training for elementary schools in Ghana. The writer adds apart from training for the regular primary, middle, and junior high schools, specialist training was also offered to train qualified teachers having an interest in the education of the blind and deaf-mute. Such teacher trainees were posted to teach in special primary and junior high schools. Trainees of the post-middle school level taught in nursery and primary schools while the post-secondary school level trained teachers taught in middle schools, currently, junior high schools.

Teacher education programs can be understood on the basis of the historical, socio-economic, political, and cultural contexts in which they have developed (Zeichner, 1994, Lewin and Stuart, 2003). Through tracing their history, some more positive aspects might be noted to help to inform our understanding of education and of the prospects of innovation (McCulloch, 1997). For these reasons, it is worth analyzing the historical development of teacher education in Ghana. Teacher training in Ghana has shifted from the four-year post middle and threeyear Post-Secondary Teacher Training programs which led to the award of certificate ' $A$ ' to the Diploma in Basic Education certificate and Post-Diploma programs through distance learning and sandwich modes alongside the traditional residential training in Colleges of Education and the accredited universities such as the UCC and the UEW. The university that trains teachers in the Visual Arts at the initial level is the University of Education, Winneba.

In addition to the traditional, residential pre-service programs presented above, other modes of teacher development are in-service programs meant to improve qualifications of serving teachers (as in the Untrained Teacher Diploma in Basic Education for untrained teachers and sandwich Diploma in Basic Education for teachers who have the initial Teachers' Certificate 'A'). There is also In-service training at school cluster and district levels meant to improve the skills, knowledge, and competences of serving teachers to improve their teaching methodology and effectiveness in the performance of their duties in general; as well as distance education programs meant to ensure continuous, lifelong teacher education process. There exists also nonresidential with pre-planned face-to-face sessions at designated centers for which students are given distancelearning materials such as printed and online self-study texts (Asare and Nti, 2014).

The current policy directives for the 3-year Diploma in Basic Education are mainly geared towards the training of generalist teachers who would be able to teach all subjects at both Primary and JHS levels; specialist teachers capable of teaching specific subjects such as Mathematics, Science and Technical at JHS level, French at both Primary JHS levels and Early Childhood Education. However, specialist training in Mathematics, Science, and Technical Skills are offered by specific colleges of Education for trainees who are being prepared for the JHS level. French and Early childhood are also options offered by specific Colleges of Education (University of Cape Coast Institute of Education, 2014). The curriculum is also intended to produce teachers who have a clear grasp of intended outcomes of their teaching activities, who are skilled in monitoring, diagnosing, and appropriately providing equal opportunity to all pupils; as well as promoting the close working relationship between Colleges of Education and local schools. This implies that, in addition to courses in Education, Practical Activities, and General Studies, students will be expected to take at least seven foundation subjects (English, Mathematics, Ghanaian Language and Culture, Environmental and Social Studies, Integrated Science, Religious and Moral Studies and Pre-Vocational Skills.

According to the University of Cape Coast Institute of Education (2014), Teacher training programs should ideally aim at achieving quality instruction to meet society's teacher demands and expectations. This, therefore, offers a new direction in the training of children to receive a quality education. The need to give general training to teachers at the pre-service stage is intended to allow them to specialize in either Primary Education or Secondary Education as they climb the professional ladder. The content, methodology, professional, and personal development courses, therefore, reflect the following generalist principles: Foundation course covering all the subjects taught at the Primary and JHS levels.

\subsection{Pre-Service Teacher Education Programmes in Ghana}

According to Anamuah-Mensah and Benneh (2002) as cited in Asare and Nti (2014), Ghana runs the following pre-service teacher education programs:

a. Three-year Diploma in Basic Education (DBE) - teachers trained in this program at the Colleges of Education are posted to the basic school which constitutes the kindergarten, primary, and junior high school.

b. Two-year post-DBE for basic school teachers - teachers are trained either in UCC or UEW, for teachers who already possess the DBE.

c. Four-year bachelor's degree for first and second cycle schools - that is a kindergarten through to Senior High School. These teachers are trained from the UCC and UEW.

d. Master's degree for second cycle schools and Colleges of Education - these teachers are trained from the 
UCC and UEW. Additionally, KNUST offers masters and doctoral degree programs in Art Education for all levels of education in Ghana even though teacher training in this institution is not mentioned in relation to specialist teacher education in Ghana.

e. Two-year DBE (sandwich) program for teachers who already possess initial professional teacher's Certificate 'A' 3-Year post-secondary qualification. This is offered through the Colleges of Education by the University of Cape Coast.

f. Four-year (distance education) Untrained Teacher's Diploma in Basic Education (UTDBE) for practicing teachers who have not received initial professional teacher training (non-professional teachers). It is offered in the Colleges of Education in partnership with the TED of the GES as an unprepared measure to increase teacher numbers to handle basic schools, especially in rural communities.

g. Three-year (distance education) Certificate 'A' program for practicing (unprofessional) teachers who were on the UTDBE program but could not meet all the requirements for the award of the UTDBE certificate. These teachers too have not received initial professional teacher training. This program is also offered in the colleges of Education in partnership with the TED of the Ghana Education Services an interim measure to increase teacher numbers to handle basic schools in rural communities.

Through the Pre-Service Teacher education programs, Anamuah-Mensah and Benneh (2002) as cited in Asare and Nti (2014) posit that teachers are trained for first cycle schools (nursery, kindergarten, primary and junior high schools), second cycle schools (senior high, vocational and technical schools) and Colleges of Education (initial teacher training institutions). Akyeampong (2003) explains that the Professional Board of the Institute of Education at the University of Cape Coast (UCC) regulates the curriculum for Initial Teacher Training. Moreover, Subject panels that include tutors of the Colleges of Education and a Chief Examiner of a subject area from recognized universities such as UCC undertake the review of the syllabi used in the training of teachers in the Colleges of Education. These panels periodically review the college curriculum under very specific guidelines from the TED that ensures the effective planning of the curriculum.

The requirements for entering the college of education as put forward by Adu-Yeboah (2016) have shifted from Middle School Leaving Certificate to West African Senior School Certificate or the Senior Secondary School Certificate. The minimum entry requirement for accessing teacher education programs is the Senior Secondary Certificate with a minimum score of aggregate 24 in six subjects. The six subjects include four core subjects and any two elective subjects. The core subjects are, English Language, Mathematics, Integrated Science, and Social Studies.

\subsection{Categories of Teachers in Ghana}

Akyeampong (2003) explains the institutional training teachers of different categories in Ghana as both a need to upgrade and train them to satisfy the needs of basic education as they change over time. He describes two categories of teachers in Ghana: one group that has professional pre-service training, with at least, a diploma qualification in general education, is classified as "professional teachers" while the other group has no professional training and is referred to as "non-professional teachers'. Graduates of universities in Ghana are usually posted to teach their specialized subjects in senior high schools and teacher training institutions; they are classified as "professional graduate teachers" if they graduate from programs of study that the Ghana Education Service recognizes as relevant to the schools and colleges curricula or had initial professional teacher training and teacher certification. Graduates in the "non-professional graduate teachers" category are usually employed to fill vacancies and may teach on a full-time basis (Akyeampong, 2003; Asuamah, 2015). Teaching in the university does not require a professional teacher training certificate (Darling-Hammond, 2000) hence 'professional' and 'non-professional' labels are not applicable to university lecturers.

\subsection{Art Teacher Education in Ghana}

Visual Arts education occurs in Ghanaian basic schools as Creative Arts for primary schools and Basic Design and Technology for Junior High Schools. To the CRDD (2007), Creative Arts are essential to the development of the cognitive, affective, and manipulative skills of the learner provide opportunities for learners to actively, participate in creative processes to enhance the growth of their imagination and self-expression. The source adds that Creative Arts provide avenues for strengthening social identity and unity of purpose, discovering the cultural heritage, and creating a unifying nation. In addition, the study of Art helps to unlock the creative potentials of learners, serves as a foundation for the development of skills in Design and Technology, and prepares learners for industrial development.

Pre-Vocational Visual Arts Related is a course of study at the Colleges of Education where teacher trainees are expected to study the course which will enable them to be able to teach Creative Arts and BDT at the basic level. The study of Pre-Vocational Arts related subjects is based on the Theory of learning by understanding, not rote learning. Practical problem-solving methods should be adopted. As much as possible, time should be spent on the teaching and learning of hands-on-activities. The essence of this program is quality education. 
The expected performance standard is $70 \%$. That is, the tutors must ensure that at least $70 \%$ of the class understand $70 \%$ of the tasks set for them and can perform at least $70 \%$ of the tasks. Emphasis must be placed on the acquisition and application, the thinking and reasoning skills (education of the head), psychomotor skills (education of the hand), and affective skills (education of the heart) (Teacher Education Division, Ghana Education Service, 2006).

The Colleges of Education in Ghana run programs with a specialization in Science/Mathematics, Mathematics/Technical Skills, French, Early Childhood Education and a General program which offers a onecredit hour course in Pre-Vocational Skills (Art Related) to first-year students on this general program option during the first semester of their study. This Pre-Vocational Skills (Art Related) course is allocated only one-hour of instructional time on the College syllabus for all teaching and learning activities and expected to cover the theory and practice or demonstration of topics that make up the course content within the allotted one hour. It is also worth noting that Pre-Vocational Skills is studied only by students on the General program in their first semester of College Education.

In the second year of study, trainees on the General program choose a specialization in one of these courses: Arts Related, Home Economics Related, Religious and Moral Education, Agricultural Science, Ghanaian Language, Music and Dance, and Physical Education. The study of Arts Related is limited to students that choose to offer Art as an elective study program. These trainees study the Principles and Methods of Teaching the Visual Arts subjects in their first semester of the second year. In the second semester of the second year, the trainees who chose to offer the Visual Arts Related continue the study of the Visual Arts Related course but select from the five courses of study for specialization: Visual Communication, Fabric, and Leather decoration, Moulding, Casting and Carving, Weaving and Stitching and Assemblage and Construction. From the above five courses, one course is selected based on the specialization of the art tutor in that college of education. On completion of the colleges of education study programs, all teachers, regardless of their elective area of study, are posted to basic schools where Creative Arts are studied in all classes at the primary school level and BDT at the JHS level. The Creative Arts curriculum integrates music, drama, dance, visual arts, etc. which further makes it difficult for teachers who studied non-visual arts-related areas to teach the subject since they have no knowledge of the topics that they did not study at college.

In view of the above, trainees are expected to teach creative arts and the BDT at the Primary or the JHS after their completion but the researcher sees the period of training as short to adequately prepare the trainees to effectively teach creative arts and the BDT at the Primary and the JHS levels of our educational system.

\subsection{Art Education in Primary School (Creative Arts Syllabus)}

From the Curriculum Research and Development Division (2007), the Creative Arts syllabus is organized in years and for each year in three Terms. Each term has areas, which are additionally composed into Units. The General Objectives stipulated by the syllabus ensures that learners:

- acquire basic knowledge, skills, and values through Performance, Composition and Two-Dimensional Art Activities such as picture making, print and pattern-making and Three-Dimensional Art Activities such as drama, singing, drumming and dancing, weaving, sewing, carving, casting, construction, modeling etc.;

- develop skills in critical, independent thinking, reasoning and imagination;

- acquire skills in self-expression;

- $\quad$ appreciate products of artists/artistes and beauty in the environment;

- develop basic knowledge, skills, and values through Performance, Composition;

- recognize the importance of originality, design and craftsmanship and performance;

The main topics in the Creative Arts syllabus are as follows

- Making Pictures, Drawing, and Colorwork

- Pattern Making, Printmaking, and Lettering

- Composition

- $\quad$ Listening and Observing

- Performance

- Weaving and Stitching

- Modeling, Casting, and Carving

- Construction/Assemblage and Paperwork

\subsection{Arts Education Curriculum}

There are several varieties of Art-Based Teaching and Learning Curriculum Models which include the Art integration model, Artful Learning ${ }^{\mathrm{TM}}$ model, and many others. In order to enroll a successful program in Art education the following practices should be taken into account to implement Art-Based teaching and learning 
models;

At the community level, Arts-Based teaching and learning may focus on improved outcomes for special populations or for the community as a whole: At the community level, arts programs used arts education, for example, to teach a skill that is transferable to the workplace, such as planning and self-assessment. Local community arts centers across the country help participants reach social and educational goals. Many of those programs reach out, in particular, to residents who are economically disadvantaged.

In education, arts-based teaching and learning activities may be implemented throughout a whole school: These practices include whole-school art activity, whole-school arts-based curricula, and comprehensive school reform. A whole-school art activity may focus on one project in which all the students in the school participate.

Other implementation models focus on arts-based teaching and learning activities at the classroom level: Classroom models bring art activities to students in a regular classroom setting. An "artist-in-the classroom" or "artist-in-residence" works cooperatively with the students' regular teacher to plan and implement art or ArtsBased lessons.

A professional development approach teaches teachers to use Arts-Based instructional strategies: This describes the preservice and in-service professional development activities designed to improve teaching through arts-based teaching and learning. Teacher training in arts-based instruction is based on the premise that the arts engage all learners. Teachers learn how to use the arts to facilitate cooperative learning groups, self-directed learning, project-based learning, and self-assessment.

Gadsden (2008) notes the increasing potential of the arts to influence pedagogy, practice, and student learning. Her extensive review of research consistently identified the potential of the arts for integrating curricula as well as the need for active inclusion of the arts in teacher preparation.

According to Bresler, (2001); Bresler \& Ardichivlli, (2002), arts integration has the potential for bridging local and global cultures across time and space, which, therefore, may have implications for teaching diverse learners, a primary concern for the 21 st century. A renewed focus on the contribution of the arts provides distinct value in the attempt to understand and address the newest and most difficult challenges associated with teaching and learning.

Pool, Dittrich, and Pool (2011) found that the Artful Learning ${ }^{\mathrm{TM}}$ model provided a successful, arts-based focus for integrating curriculum in the teacher education program. Artful Learning ${ }^{\mathrm{TM}}$ (1996) focuses on K-12 school improvement and was inspired by the vision of Leonard Bernstein, who observed that the artistic process for both creating and experiencing art is a fundamental way of learning in any discipline. In addition to its artsbased focus, the Artful Learning ${ }^{\mathrm{TM}}$ model is concept-based and interdisciplinary, with teaching and learning centered on the exploration of masterworks, the asking of essential questions, rigorous scholarship, active creation, and deep reflection (Wiggins \& McTighe, 2005).

The core of Artful Learning ${ }^{\mathrm{TM}}$ encompasses a four-phase learning sequence: experience, inquire, create, and reflect. The learning sequence unfolds in an active, hands-on manner, with teachers and students sharing the roles of artist, teacher, and scholar. At Gettysburg College, the Artful Learning ${ }^{\mathrm{TM}}$ model was used successfully in undergraduate college settings (Robertson, 2007; Dittrich, Pool, Stebick, \& Weigler, 2008; Robertson, 2007; Dittrich and Pool, 2008).

Education policies almost universally recognize the value of arts. In the United States of America, fortyseven states have arts-education mandates, forty-eight have arts-education standards, and forty have arts requirements for high school graduation, according to the 2007-08 Arts Education Partnership (AEP) state policy database. The Goals 2000 Educate America Act, passed in 1994 to set the school-reform agenda of the Clinton and Bush administrations, declared art to be part of what all schools should teach. No Child Left Behind (NCLB), enacted in 2001, included art as one of the ten core academic subjects of public education, a designation that qualified arts programs for a range of national grants (Smith, 2009).

UNESCO (2015) states that good curriculum plays an important role in forging life-long learning competencies, as well as social attitudes and skills, such as tolerance and respect, constructive management of diversity, peaceful conflict management, promotion and respect of Human Rights, gender equality, justice, and inclusiveness. At the same time, the curriculum contributes to the development of thinking skills and the acquisition of relevant knowledge that learners need to apply in the context of their studies, daily life, and careers. The curriculum is also increasingly called upon to support the learners' personal development by contributing to enhancing their self-respect and confidence, motivation, and aspirations.

\section{Methodology}

The study employed the qualitative and quantitative research design to investigate the current conditions of teaching and learning of creative arts at the basic level in Ghanaian public schools in the northern region of Ghana. The descriptive, survey methods, and document analysis were used to have detailed knowledge of teaching and learning conditions in the five sampled districts. Data were collected through observation, questionnaires, and interviews as instruments for data collection. 


\subsection{Population}

The Northern Region, which occupies an area of about 70,383 square kilometers, is the largest region in Ghana in terms of land area. It shares boundaries with the Upper East and the Upper West regions to the north, the Brong Ahafo and the Volta Regions to the south, and two neighboring countries - the Republic of Togo to the east, and La Cote d' Ivoire to the west. The land is mostly low lying except in the northeastern corner which has the Gambaga escarpment and its western corridor.

Five Metropolis, Municipal and Districts (MMDs) namely, Tamale Metropolis, Yendi Municipal, Sagnarigu, Tolon and Kumbungu Districts in the Northern Region were the setting of the study. These districts were selected based on proximity and how properly they represent the MMDs in the region in terms of being municipal, metropolitan, or a district assembly. This was to ensure that the results of the study could be generalized to all the districts in the region.

Gender information was recorded from the questionnaire. Out of the 410 total respondents during the study, 190 were males while 220 were females. The number of male headteachers and teachers made $46.3 \%$ of the total respondents while $53.7 \%$ were female teachers. The number of females in the teaching field is higher in the studied MMDs.

Table 1: Teachers and Head Teachers from various MMDs

\begin{tabular}{|l|llll|}
\hline MMDs & $\begin{array}{l}\text { No. of } \\
\text { Schools }\end{array}$ & No. of Teachers & $\begin{array}{l}\text { No. of } \\
\text { Headteachers }\end{array}$ & $\begin{array}{l}\text { Total No. of } \\
\text { Teachers and } \\
\text { Headteachers }\end{array}$ \\
\hline Tamale Metropolis & 20 & 122 & 20 & 142 \\
Yendi Municipal & 15 & 70 & 15 & 85 \\
Sagnarigu & 10 & 53 & 10 & 63 \\
Tolon & 10 & 48 & 10 & 58 \\
Kumbungu & 10 & 52 & 10 & 62 \\
\hline Total & $\mathbf{6 5}$ & $\mathbf{3 4 5}$ & $\mathbf{6 5}$ & $\mathbf{4 1 0}$ \\
\hline
\end{tabular}

In this article, the researcher used on-the-spot observation at the (65) primary schools in the study area to look for more information on the teaching and learning of Creative Arts in the primary schools and to observe things critically for better understanding. This assisted the researcher to get a vivid and visual understanding of what goes into the teaching and learning of Creative Arts in the basic schools in the Northern Region of Ghana.

The researcher conducted an observational study on 195 teachers representing $57.0 \%$ of the total teachers sampled for the study. The Tamale Metropolis was 80 teachers representing $66.0 \%$, Yendi Municipal was 40 teachers representing 57.0\%, Sagnarigu District was 30 teachers also representing 57.0\%, Tolon District was 20 teachers representing 42.0\% and Kumbungu District was 25 teachers representing $48.0 \%$ in the Northern Region for observing to bring to light what actually goes during the teaching and learning of the Creative Arts. This was to give the researcher the first-hand information rather than relying on the information teachers provided through the questionnaires and interviews. The researcher used an observation guide that focused on teaching and learning of creative arts in areas of lesson notes, the use of Teaching and Learning Materials, Teacher-learner Activities, teaching aids, and the confidence level of the teachers on the teaching of Creative Arts.

The observation was carried out on 195 teachers representing $57.0 \%$ of the total teachers sampled for the study. The Tamale Metropolis was 80 teachers representing 66.0\%, Yendi Municipal was 40 teachers representing 57.0\%, Sagnarigu District was 30 teachers also representing 57.0\%, Tolon District was 20 teachers representing 42.0\% and Kumbungu District was 25 teachers representing $48.0 \%$ in the Northern Region for observing to bring to light what goes during the teaching and learning of the Creative Arts.

\section{Findings and Discussions}

The paper revealed that the contact hours at the Colleges of Education contributes to the problem, this is because the one credit hour is not enough to adequately equip teacher trainees to adequately deliver the creative lesson at the primary schools and the teachers who are trained as specialized teachers to teach some particular subjects like science and mathematics who did not learn anything and about the arts are also found teaching creative arts. After all, they found themselves at the primary schools after completing their study.

\subsection{Programs Studied by Teachers at college of education}

Assessing the expertise of teachers in the districts and the pedagogical content they taught at the various schools revealed that most of them are specially trained for other subjects other than arts-related subjects. Out of the 345 teachers interviewed, 290 specialized in other electives such as Ghanaian language, Religious and Moral Education (RME), Home Economics Related, and Agricultural Studies, which are not related to Pre-Vocational Skills in the Visual Arts in content. There are only 58 teachers in the five MMDs that were actually trained as art teachers. Figure 1 shows the electives studied by the teachers at their colleges of education. 
From Figure 1, only $16.81 \%$ of the teachers studied visual arts and are well equipped to teach Creative Arts.

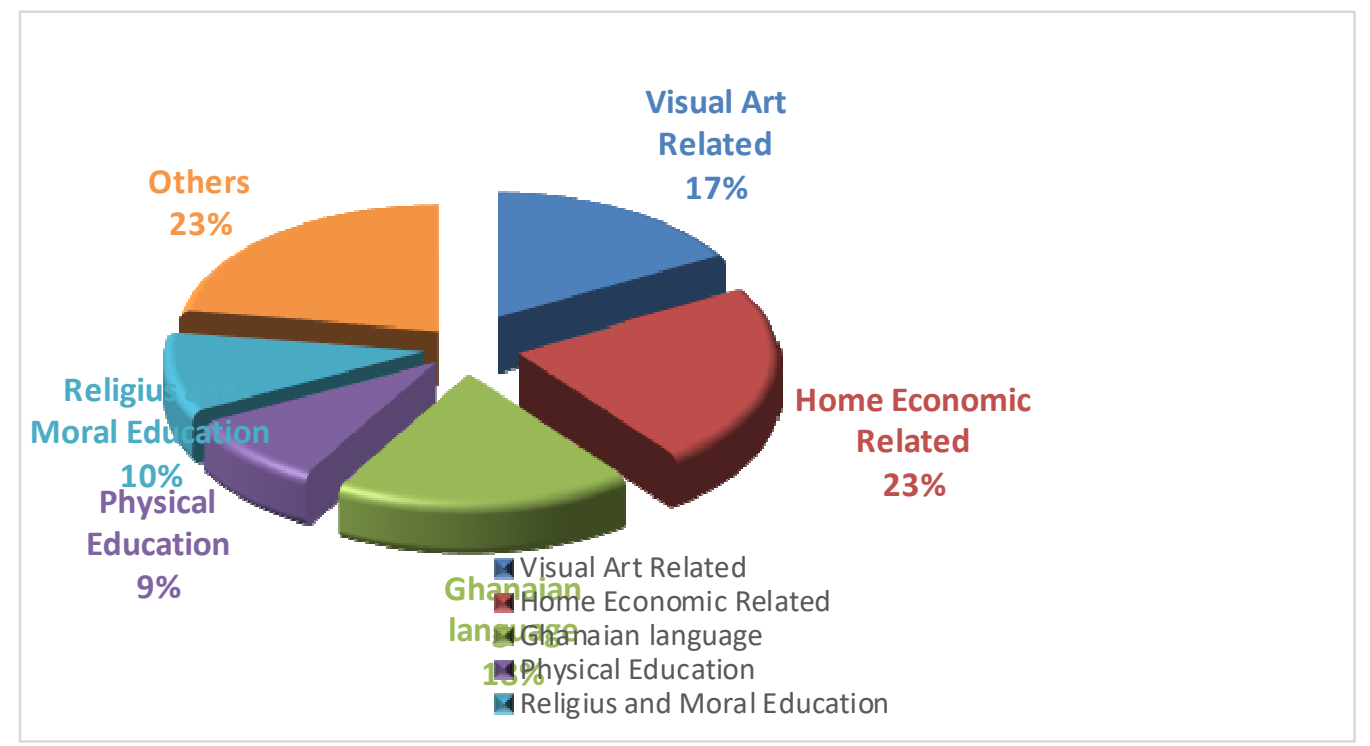

Figure 1. Elective Subjects of Study at Colleges of Education

The remaining $73.19 \%$ mastered in electives that are not pre-vocational skills or arts-related and had only undertaken just a credit hour of the Fundamentals in Visual Arts Related subject. This affirms the argument by the researcher that a credit hour lesson per week at the colleges of education, is inadequate to properly train a teacher for a subject that requires practical and theoretical engagements. This is because the teachers will be illprepared in the area of skills acquisition to effectively teach pupils visual art especially in the area of practical lessons.

\subsection{The teaching of the Creative Arts Subject}

Out of the 345 respondents, only 48 of them do not teach Creative Arts in addition to their expertise. The remaining 297 teachers teach Creative Arts. Out of the 297 teachings the subject, $87.9 \%$ of them studied other electives not arts-related.
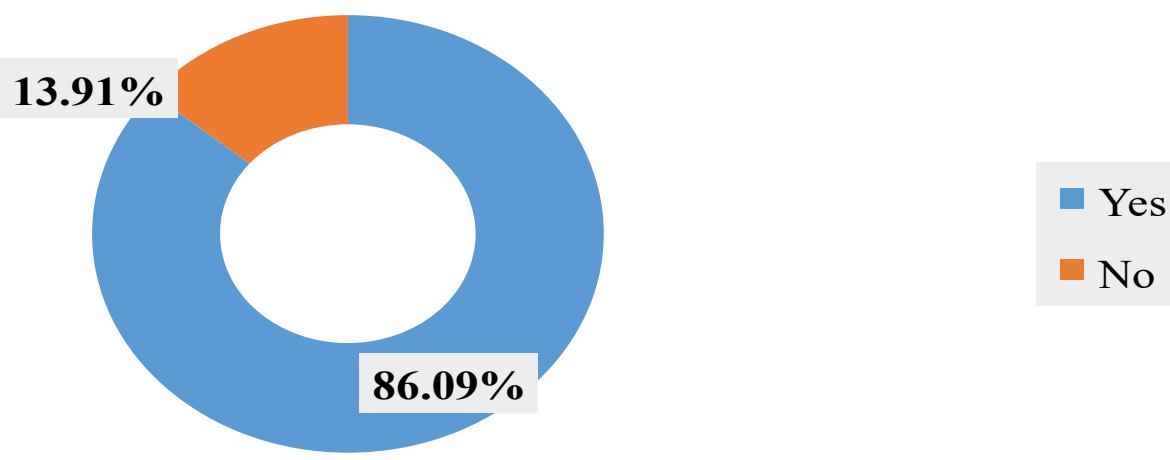

Figure 2. Number of Teachers Teaching Creative Arts Subject

From Figure 2, $86.09 \%$ of the total 345 teachers are Creative Arts teachers while the remaining $13.91 \%$ of teachers are relieved of the responsibility to teach the subject. This implies that the possibility of most trained teachers being given the onus to teach the subject is high therefore, the need for the necessary measures to be in place to foster effective training.

5.3 The Link between what is learned at the Colleges and what is Taught

The argument for the absence of a link between course content at training Colleges and the teaching field is evident. This was confirmed by 178 out of the 345 respondents. 


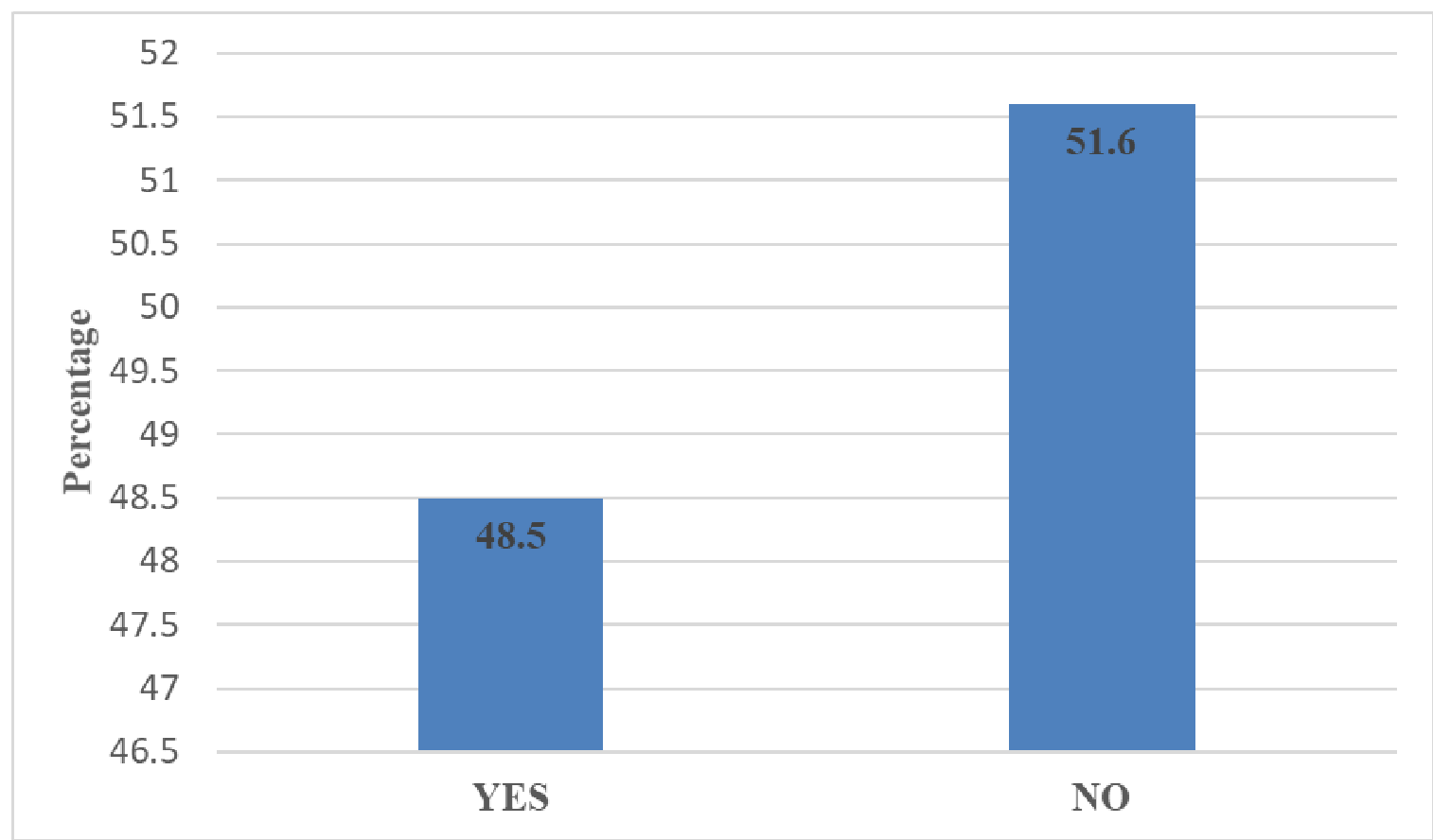

Figure 3. Relationship between Teacher training and Teacher practice

From Figure 3, 51.6 \% of the respondents denied any link between their training and teaching while the remaining $48.4 \%$ of the teachers affirm the existence of such a link between taught and practice. This implies the need to revisit training given to trainees at the various colleges pertaining to the arts. This will oversee better Creative Arts education in Ghana and produce graduates who will develop greater interest in the field and delve further at higher levels of the educational ladder.

\subsection{The use of teaching and learning materials during training}

The use of teaching and learning materials is integral to the effectiveness of Creative Arts education. Teachers ought to be in the position to use TLMs in the subject's facilitation to help pupils grasp what is taught in the class. The response from the field was to find out if teachers were taught how to use TLMs as displayed by the bar chart.

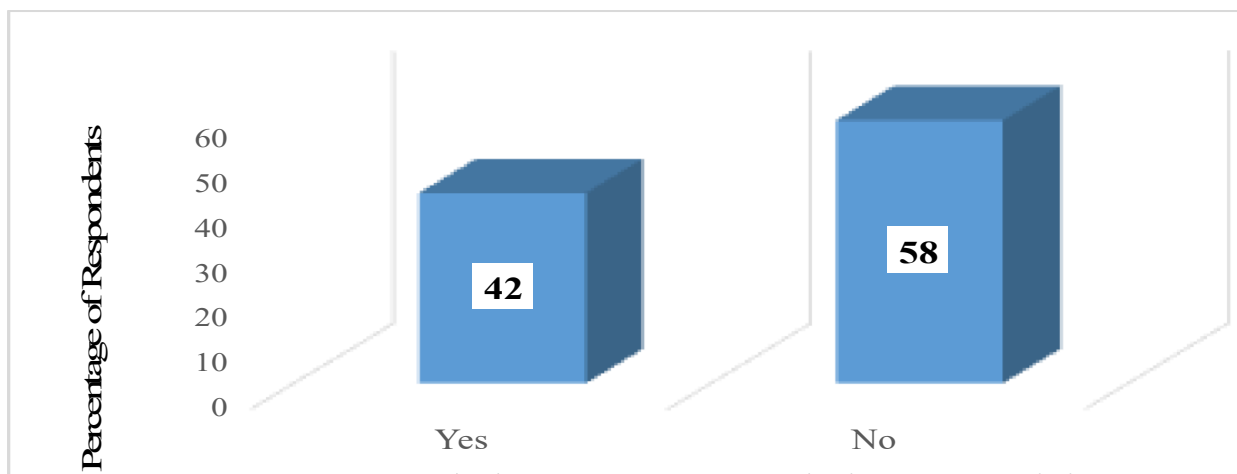

Were you taught how to use TML's during your training

Figure 4. Teachers' Response to Teacher and Learner Resources Knowledge

From figure 4, $58 \%$ of respondents indicate that they were not taught how to use TLMs while the remaining $42 \%$ had been trained on how to use it to facilitate teaching. The increasing percentage of teachers without training will affect the practical aspect of the arts. This is because they are not familiar with their use and will be reluctant to inculcate the practical aspect of the course that requires them to use TLMs.

\section{Conclusions}

The arts education has faced many challenges resulting in a negative impact on pupils in Ghana. Pupils do not receive the right pedagogical content knowledge necessary to enable practical skill development to effectively equip them with the required developmental skills to realize their potentials. This is attributed to the lack of necessary teaching and learning materials, less practical lessons, and the support systems that will facilitate the 
effectiveness of the subject in the basic school curriculum. Teachers' contribution to skill development through their teaching methods is affected by the pre-service training received at the college of education. This defect is an inadequacy created by the college curriculum resulting in a content mismatch between pre-service and inservice curriculum. The result is difficulty in effectively facilitating learning for pupils.

Response to the identified impediments to effective Creative Arts education should address the shortfalls in the training system to aid in the presentation of teachers who will be confidently prepared to assist the subject facilitation. The identified teaching and learning materials, inculcating practical activities into pupils' training, and provision of identified support systems will guarantee effective of Arts education and advance Creative Arts training in the northern region of Ghana.

\section{References}

Adu-Yeboah, C. (2016). Teacher preparation and continuing professional development in Africa: Learning to teach reading and mathematics and its influence on practice in Ghana. Draft Country Report: Centre for International Education: University of Sussex.

Afum-Danso, E. (2012). An Overview of Teaching/Learning of Creativity in the Colleges of Education in BrongAhafo Region: A Case Study of Berekum College of Education (Doctoral dissertation).

Akyeampong, A. (2003). Teacher Training in Ghana-Does It Count? Multi-Site Teacher Education Project (MUSTER): Country Report One. DfID.

Anamuah-Mensah, J. (2011). Meeting the challenges of education in the twenty-first century.

Asare, K. B., \& Nti, S. K. (2014). Teacher education in Ghana: A contemporary synopsis and matters arising. SAGE Open, 4(2), 2158244014529781.

Asuamah, A. S. Y. (2015). Graduate artists in the classroom: the state of non-professional graduate teachers in Ghana (Doctoral dissertation).

Benneh, M. (2006). Particular issues on teacher education and training in Ghana. Dakar, Senegal.

Bresler, L. (2001). Agenda for arts education research: Emerging issues and directions. In M. M., Enlightened advocacy: Implications for research for arts education policy and practice (pp. 43-71). College Park, MD: University of Maryland.

Bresler, L., \& Ardichivlli, A. (2002). International research in education. Dordrecht, Netherlands: Springer.

Darling-Hammond, L. (2000). Teacher quality and student achievement. Education policy analysis archives, $8,1$.

Dittrich, C., Pool, J., Stebick, D., \& Weigler, E. (2008). Revisiting on-line discussion as practice for reflective thinking in three sequential classes. Hawaii International Conference on Education. Honolulu

Farrant, J. S. (1982). Developing Countries. Changing priorities in teacher education. London: Croom Helem Ltd.

Gadsden, V. (2008). The arts and education: Knowledge generation, pedagogy, and the discourse of learning. Review of Research in Education, 29-61.

Guadalupe, M., \& Wulf, J. (2010). The flattening firm and product market competition: The effect of trade liberalization on corporate hierarchies. American Economic Journal: Applied Economics, 2(4), 105-27.

Hollins, E. R. (2011). Teacher preparation for quality teaching. Journal of Teacher Education, 62(4), 395-407.

Institute of Education, University of Cape Coast. (2014). Draft Three-Year Diploma in Basic Education FiveSemester Programme Revised Syllabus. Cape Coast: Institute of Education, University of Cape Coast.

Lewin, K. M., \& Stuart, J. S. (2003). Researching Teacher Education: New Perspectives on Practice, Performance, and Policy, Multi-Site Teacher Education Research Project (MUSTER), Synthesis Report (No. 666-2016-45491).

McCulloch, G. (1997). Marketing the millennium: Education for the twenty-first century. In A. Hargreaves, \& R. Evans, Beyond educational reform: Bringing teacher back in (pp. 52-71). Buckingham: Open University.

Njui, H. W. (2017). Teacher Education In Contemporary Society: Transforming Teacher Education Through Technology Integration In Learning. European Journal of Education Studies.

Pool, J., Dittrich, C., \& Pool, K. (2011). Arts Integration in Teacher Preparation: Teaching the Teachers. Journal for Learning through the Arts, 2.

Robertson, M. (2007). Artful learning goes to college. Prelude, fugue, riffs. New York: Leonard Bernstein Foundation.

Rouse, M. (2008). Developing inclusive practice: A role for teachers and teacher education. Education in the North, 16(1), 6-13.

Scott, P. (2005). The Globalization of Higher Education. In Higher Education Reformed (pp. 101-118). Routledge.

Teacher Education Division, Ghana Education Service. (2006). Pre-Vocational Skills Art Related Teaching Syllabus. Accra: Teacher Education Division.
UNESCO.
(2015).
Curriculum.
Retrieved
from
Education: http:/www.unesco.org/new/en/education/themes/strengthening-education-systems/quality-framework/core- 
resources/curriculum/

Wiggins, G., \& McTighe, J. (2005). Understanding by design. Alexandria, VA: ASCD.

Wikipedia (2014). Art school. Retrieved June 23th, 2018 from http://en.wikipedia.org/wiki/Art_school.

Zeichner, K. M. (1994). Research on teacher thinking and different views of reflective practice in teaching and teacher education. Teachers' minds and actions: Research on teachers' thinking and practice, 9-27. 